\title{
Proposals Concerning the Higher Taxa of Bacteria
}

\author{
N. E. GIBBONS† AND R. G. E. MURRAY \\ Department of Bacteriology and Immunology, University of Western Ontario, London, Ontario, \\ Canada N6A 5C1
}

\begin{abstract}
Names are proposed for divisions, classes, and some orders of bacteria. The kingdom Procaryotae Murray 1968 is divided into three divisions: Gracilicutes divisio nov., Firmacutes divisio nov., and Mollicutes Edward and Freundt 1967, for organisms having, respectively, a gram-negative cell wall, a gram-positive cell wall, and no cell wall. Gracilicutes comprises the class Photobacteria classis nov. for organisms having a phototrophic metabolism and Scotobacteria classis nov. for those having a nonphototrophic metabolism. Photobacteria is divided into two subclasses: Oxyphotobacteriae subclassis nov. for organisms that carry out an aerobic phototrophic metabolism, using water as an electron donor and producing oxygen, and Anoxyphotobacteriae subclassis nov. for those that have an anaerobic phototrophic metabolism. Oxyphotobacteriae comprises the orders Cyanobacteriales ordo nov. (formerly blue-green algae) and Prochlorales Lewin 1977. Anoxyphotobacteriae contains the order Rhodospirillales Pfennig and Trüper 1971 and Chlorobiales ordo nov. The possible need of a fourth division to include organisms that have a rigid cell wall but do not contain peptidoglycan is noted. The name proposed for such a division is Mendocutes, that is, organisms having a cell wall with faults and blemishes.
\end{abstract}

In the 8th edition of Bergey's Manual of Determinative Bacteriology (4), the Editorial Board of the Manual accepted the kingdom name Procaryotae Murray 1968, 252 (20) but was not prepared to support formal names for subdivisions of the kingdom and thus used the vernacular designations "The Cyanobacteria" and "The Bacteria." However, Murray (21), in an introductory chapter to the Manual, made some suggestions, again mostly in the form of vernacular names, as a basis for the further separation of the taxa of bacteria. These have been discussed further, and a formal nomenclature is now proposed.

The division of the living world (on the basis of cellular organization) into procaryotes and eucaryotes was first proposed by Chatton (5). Since the recognition by Stanier (27) and Stanier and van Niel (29) of the utility of this fundamental approach, there has been wide acceptance of it by those interested in general systematics, e.g., Murray (20), Allsopp (1), Whittaker (33), and Margulis (18). Allsopp (1) stated “... all organisms can be separated into two major Kingdoms, the Procaryota, which comprise the Bacteria and Cyanophyta, and the Eucaryota which includes all other organisms whether plants, animals or protists." Whittaker (33), while accepting the fundamental dichotomy, still included the procaryotes in the kingdom $\mathrm{Mo}$ nera, a name first proposed by Haeckel in 1866

† Deceased 10 December 1977. (even though Haeckel later accepted Schizophyta Cohn) for a miscellaneous group of organisms under Protista. Copeland (7) accepted Monera as one of his four kingdoms, preferring this name to Schizophyta Cohn 1875 , which implies an association with plants. Bacteriologists mostly ignored the kingdom name Monera, although Stanier and van Niel (28) accepted it in their critique of the 5th edition of Bergey's Manual. But even in the 7th edition of the Manual (3), Protophyta Sachs 1874 was accepted as a division of the plant kingdom, with Schizophyta Cohn as a synonym.

Margulis (18) has proposed Prokaryota and Eukaryota as superkingdoms. Although such a rank may be useful for the eucaryotes, so that the time-honored kingdoms Plantae and Animalia may be retained, the need for such a super-rank for Procaryotae is debatable. Although Murray (20) did suggest the taxon Procaryotae "at the highest level" and appropriately at the same level as Eucaryotae, there seems no need for the superkingdom Procaryotae, the kingdom Monera, and subkingdoms for the bacteria and aerobic photosynthesizers as proposed by Margulis. Whether both a superkingdom and a kingdom are required for harmony with Eucaryotae is another matter and should be of concern to botanical and zoological taxonomists. Lewin (15) sees no point in making "prokaryota" synonymous with "bacteria" and seemingly prefers to consider the blue-green procaryotes as algae. If this conservative point of 
view is generally shared by cyanophycologists, a subkingdom for the blue-greens may appeal to them. We still consider procaryotes and bacteria as synonymous.

The 8th edition of Bergey's Manual has recently been criticized by Sonea and Panisset (26) as ignoring the distinct and unifying aspect of bacterial genetics. These authors present the view that "instead of accepting the existence of species, genera or families (and presumably higher taxa) in the bacterial world, we consider that the planetary clone consists of many distinctly differentiated cells, as in the case of an individual tree or an individual animal." However, they admit that "these currently used names should be kept for practical purposes, even if we know that no speciation exists among bacteria." (Quotations are from English summary.) Studies of deoxyribonucleic acid and ribonucleic acid and hybridization experiments will presumably provide fundamental data to illuminate such problems. There is close to a century of biological study indicating that many elements of the planetary clone are of sufficient stability to be recognized, whenever they are isolated, by the characters they exhibit and that recognition is a practical necessity. Actually the organisms seem more stable than either the names or the bacteriologists who coin them. So for the present, we prefer to think of a bacterial kingdom rather than a planetary clone, and divisions and classes seem more practical than subclones for the varied and complex groups considered below.

Formal names are proposed for the higher taxa of bacteria, based on the vernacular names proposed by Murray (21, p. 9) but including suggestions derived from discussions with colleagues.

The kingdom Procaryotae Murray 1968, 252 is divided on the basis of cell wall types into three divisions: (i) Gracilicutes divisio nov., (type division) which possesses the gram-negative type of cell wall; (ii) Firmacutes divisio nov., which possesses the gram-positive type of cell wall (which is usually thicker and less differentiated than the gram-negative type); and (iii) Mollicutes (Edward and Freundt) divisio nov., which lacks a true cell wall. These three groups, suggested by Murray in 1962 (19), have determinative value. They conserve, for the most part, the general arrangement used in the 8th edition of Bergey's Manual, although, except for Mollicutes, formal ranks were not assigned. A fourth division may be needed for organisms that do not have a clear-cut type of cell wall containing peptidoglycan, such as some, if not all, of the methane bacteria, halophilic bacteria, and Sulfolobus. These can be assem- bled conveniently into a fourth division for which we propose the name Mendocutes (from the Latin adjective mendosus, having faults, blemishes). This division logically would precede Mollicutes in a hierarchical classification.

Division I Gracilicutes contains two classes: (i) Photobacteria classis nov. (type class) and (ii) Scotobacteria classis nov. for the photosynthetic and nonphotosynthetic bacteria, respectively. The Bacteriological Code (14) is not altogether clear on the naming of higher taxa. Rule 7 (Names of Taxa above the Rank of Genus) could apply to all higher taxa. It states quite specifically that the name of a taxon "is in the feminine gender, plural number, ..." However, Rule 8 (Names of Taxa above the Rank of Order) seems to negate Rule 7 at this rank and above, since it simply indicates that the name is a Latin or Latinized word. Furthermore, one of the examples given, Schizomycetes, is a masculine, plural word. We, therefore, feel justified in using neuter, plural nouns for these classes.

Class Photobacteria comprises two subclasses: (i) Oxyphotobacteriae subclassis nov. (type subclass) and (ii) Anoxyphotobacteriae subclassis nov.

The subclass Oxyphotobacteriae includes organisms which, by using water as an electron donor, produce oxygen in the light. For some time, all of the blue-green bacteria have been considered as belonging to a single order. Recently, Lewin (16) suggested a new division, Prochlorophyta, for unicellular, bright green, spherical procaryotes that contain chlorophylls $a$ and $b$, do not contain any detectable bilin pigments, and show no evidence of phycobilisomes on the thylakoids. He has now (17) suggested that these organisms belong to the genus Prochloron in the family Prochloroaceae in the order Prochlorales. As procaryotes, these undoubtedly belong in the subclass Oxyphotobacteriae, and we propose that this subclass comprise the order Cyanobacteriales Stanier ordo nov. (type order) to include all blue-green bacteria other than those in the order Prochlorales Lewin 1977, 217.

The subelass Anoxyphotobacteriae circumscribes organisms that carry out a phototrophic metabolism under anaerobic conditions. It is proposed that the subclass comprise the orders (i) Rhodospirillales Pfennig and Trüper 1971, 17 (type order) and (ii) Chlorobiales ordo nov.; this dichotomy is thus made at the ordinal level rather than the subordinal level as proposed by Trüper (30).

No attempt is made to subdivide class II Scotobacteria. Names could be assigned based on parts 2 to 12 and 18 of the 8th edition of the 
Manual, but it is interesting that the authors of these parts and sections provided only five names at the ordinal level. A perusal of "Further Comments" indicates quite clearly that a great deal more work is needed before ranks may be assigned to the many subgroups in this class. However, the order Pseudomonadales OrlaJensen 1921, 270 is suggested as the type.

The details of the classification and nomenclature proposed here are as follows:

\section{Kingdom Procaryotae Murray 1968, 252}

(Monera Haeckel emend. Copeland 1938, 416; in part Protista Haeckel 1866, 19; $M y$. chota Enderlein 1925, 236.) Pro.car.y.o'tae. Gr. pref. pro before (primordial); Gr. n. karyon nut, kernel (nucleus); M.L. fem. pl. n. Procaryotae organisms with a primordial nucleus.

Single cells or simple associations of similar cells containing a nucleus (genophore) that is never separated from the cytoplasm by a nuclear membrane. Cell division is not accompanied by changes in the texture or staining properties of either nucleoplasm or cytoplasm. Organelles enclosed and isolated by unit membranes are absent. Ribosomes of the 70S type are disposed in the cytoplasm and not on an endoplasmic reticulum. Cytoplasmic streaming, pseudopodial movement, endocytosis, and exocytosis are not observed. The formation of haploid gametes by meiosis and the subsequent formation of a diploid zygote by gametic fusion do not occur.

With few exceptions (Mollicutes), the cells are contained within a rigid or semirigid cell wall conferring a constancy of shape including spherical, rod, vibrio, helical, and filamentous forms. The cell associations are based upon growth habit, planes of division, and cell separation. Cell multiplication involves growth and division, usually binary and occasionally unequal, in some groups by multiple fission and in others by budding. Cells may remain attached after division, causing cell aggregates, the gross form of which is determined by the relations between the planes of successive cell divisions; true branching may occur in certain species.

Division I. Gracilicutes divisio nov. (type division)

Gra.cil.i.cu'tes. L. adj. gracilis thin: L. fem.

n. cutis skin; M.L. fem. pl. n. Gracilicutes

division with thinner cell walls, implying a

gram-negative type of cell wall.

Phototrophic and nonphototrophic bacteria that have a cell wall structure consistent with a gram-negative reaction (24), usually possessing both an outer membrane and an inner, thin, peptidoglycan layer. Cells may be spheres, ovals, straight or curved rods, spirals, or filaments; some of the filaments may be sheathed. Reproduction is mainly by binary fission; in some groups it is by budding. In one group (Myxobacterales), fruiting bodies and myxospores may be produced. Spores are not formed. Many organisms are motile by means of flagella; some have gliding motility. These organisms may be aerobic, anaerobic, or facultatively anaerobic.

Class I. Photobacteria classis nov. (type class) Pho.to.bac.ter'i.a. Gr. n. phos, photos light; Gr. neut. dim. n. bakterion a small rod; -ia proposed ending for class; M.L. neut. pl. $n$. Photobacteria light-requiring bacteria.

Procaryotes able to carry out photosynthesis, either oxygenic or anoxygenic. Photopigments may be chlorophyll $a$ or $b$, or bacterial chlorophyll $a, b, c, d$, or $e$.

Subclass I. Oxyphotobacteriae subclassis nov. (type subclass)

Ox.y.pho.to.bac.ter'i.ae. Gr. adj. oxys sharp, acid (oxygen); Gr. n. phos, photos light; Gr. neut. dim. n. bakterion a small rod; M.L. fem. pl. n. Oxyphotobacteriae light-requiring bacteria that produce oxygen.

Procaryotes that possess photosystems I and II, use water as an electron donor and, hence, produce oxygen in light. Cells contain chlorophyll $a$, or $a$ and $b$. Cells enclosed in a rigid, multilayered wall with an inner peptidoglycan layer. May be motile at some stage of development; motility is always of the gliding type and is dependent on surface contact.

Order I. Cyanobacteriales Stanier ordo nov. (type order) (This order is attributed to R. Y. Stanier, who was one of the first, if not the first, to use the term "cyanobacteria." He also supplied most of the description of the order.)

(Myxophykae [sic] Wallroth 1833, 4; Phycochromophyces Rabenhorst 1863; Cyanophyceen Sachs 1874, 249; Schizophyceae Kirchner 1878, 39.) Cy.an'o.bac.ter.al'es. Gr. adj. cyaneos dark blue; Gr. dim. n. bakter- • ion a small rod; -ales ending to denote order; M.L. fem. pl. n. Cyanobacteriales the order of blue-green bacteria.

Cyanobacteria contain only one chlorophyll, $a$, various carotenoids, and at least three molecular classes of phycobiliproteins (allophycocyanin B, allophycocyanin, and phycocyanin). Some also contain phycoerythrin or phycoerythrocyanin. Chlorophyll and carotenoids are characteristically located in a system of thylakoids, internal to the cytoplasmic membrane; the phycobiliproteins are located in disk-shaped granules; and the phycobilisomes are attached to the outer faces of the thylakoids. Rarely, thylakoids are 
absent; in this case, the cytoplasmic membrane is the site of chlorophyll and carotenoids, phycobiliproteins being incorporated in a cortical layer contiguous with the inner face of the cytoplasmic membrane. Aerobic photoautotrophs; some can perform facultative anoxygenic photosynthesis, using $\mathrm{H}_{2} \mathrm{~S}$ as a reductant. Some but not all are facultative heterotrophs: dark metabolism is respiratory. All cyanobacteria form cyanophycin, a copolymer of arginine and aspartic acid, as a nitrogenous organic-reserve material.

In structural aspects the order is diverse. Some cyanobacteria are unicellular, reproducing by binary fission, multiple fission, or budding, and in some cases producing aggregates of cells. Others are filamentous; growth occurs by repeated intercalary cell divisions, and reproduction is either by random filament breakage or by formation of short, motile chains of cells (hormogonia). The filament may be uniseriate and unbranched or multiseriate and branched. When grown aerobically in the absence of combined nitrogen, many filamentous cyanobacteria produce within the filament differentiated cells known as heterocysts, distinguishable by heavy envelopes, less intense pigmentation, and refractile polar granules. Mature heterocysts do not grow or divide; they serve as the cellular sites of nitrogen fixation in the filament. Some heterocystous cyanobacteria also form thick-walled resting cells (akinetes), which germinate to produce a hormogonium. Cyanobacteria are either motile by gliding or are not motile.

Subdivision of the order is not proposed. Until recently, very few cyanobacteria had been isolated in pure culture; consequently, systematic comparative studies of the group by bacteriological methods are still fragmentary. It is also evident, however, that the phycological classification, based on properties determined on natural populations, is inadequate and still requires major revision.

Order II. Prochlorales Lewin 1977, 217

Cells contain both chlorophylls $a$ and $b$; phycobiliproteins are not present. Unicellular organisms which reproduce by binary fission.

\section{Subclass II. Anoxyphotobacteriae subclassis} nov.

An.ox.y.pho.to.bac.ter'i.ae. Gr. pref. an not, without; Gr. adj. oxys sharp, acid (oxygen); Gr. n. phos, photos light; Gr. dim. n. bakterion a small rod; M.L. fem. pl. n. Anoxypho. tobacteria light-requiring bacteria that do not produce oxygen.

Procaryotes capable of carrying out a photolithotrophic and/or photoorganotrophic metabolism under anaerobic conditions by using pho- tosystem I. Cells contain bacteriochlorophyll $a$, $b, c, d$, or $e$ and various carotenoids: photopigments are located on internal membrane systems of different morphology, which systems are continuous with the cytoplasmic membrane, or in "chlorobium vesicles," which underlie and are attached to the cytoplasmic membrane.

\section{Order I. Rhodospirillales Pfennig and Trüper 1971, 17 (type order)}

Procaryotes with cell membranes containing bacteriochlorophyll $a$ or $b$ and various carotenoids; photopigments are located on internal membrane systems, which are of different morphology and are continuous with the cytoplasmic membrane. Motility, when it occurs, is by means of flagella.

The order contains the previously described families Rhodospirillaceae Pfennig and Trüper 1971, 17 and Chromatiaceae Bavendamm 1924, 125.

\section{Order II. Chlorobiales ordo nov.}

(Chlorobineae Trüper 1976, 74.) Chlo. ro.bi.al'es. M.L. fem. pl. n. Chlorobiaceae type family of order; -ales ending to denote order; M.L. fem. pl. n. Chlorobiales the Chlorobiacene order.

Procaryotes containing bacteriochlorophyll $c$, $d$, or $e$, and small amounts of $a$ as well as various carotenoids; the photopigments are located in "chlorobium vesicles," which underlie and are attached to the cytoplasmic membrane. Either nonmotile or motile by gliding.

This order contains the previously described families Chlorobiaceae Copeland 1956, 31 (type family) and Chloroflexaceae Trüper 1976, 74.

\section{Class II. Scotobacteria classis nov.}

(Schizomycetes von Naegeli 1857, 760; Bacteriaceae Cohn 1872, 237; Bacteria Haeckel 1894, 140; Schizomycetes Stanier and van Niel 1941, 458.) Sco.to.bac.ter'i.a. Gr. n. skotos darkness; Gr. dim. n. bakterion a small rod; -ia proposed ending for class; M.L. neut. pl. n. Scotobacteria bacteria that do not require light for metabolism.

Procaryotic organisms that do not have a photosynthetic metabolism. In fluid environments, they may exhibit swimming motility and possess flagella of the bacterial type; other organisms show gliding, twitching, snapping, and darting movements on the surface of solid media. Endospores are formed in some genera; arthrospores and cysts are formed in some others; heterocysts are not formed. These organisms may be aerobic, anaerobic, or facultatively anaerobic. 
Division II. Firmacutes divisio nov.

Fir.ma.cu'tes. L. adj. firmus strong, stout, durable; L. fem. n. cutis skin; M.L. fem. pl. n. Firmacutes division with thick and strong skin, to indicate gram-positive type of cell wall.

Procaryotes having a gram-positive type of cell wall (24). Reproduction mainly by binary fission. Cells may be spheres, rods, or filaments; the filaments may be branching or nonbranching. Some form endospores; some produce spores on hyphae or in sporangia. Some are motile by means of flagella; the majority are nonmotile. These organisms may be aerobic, anaerobic, or facultatively anaerobic.

Several orders that cover some of the groups in this division are listed in Index Bergeyana. Actinomycetales Buchanan 1917, 162 was the only order provided by the authors of the 8th edition of the Manual, and it might be considered the type order on the basis of priority. However, Bacillales Pribram 1933, 79 is proposed as the type order, based on the priority of the genus Bacillus Cohn 1972 over Actinomyces Harz 1877. It is also a more typical representative of gram-positive organisms.

Division III. Mollicutes (Edward and Freundt) divisio nov. (Class Mollicutes Edward and Freundt 1967, 267)

Procaryotic organisms that lack a cell wall and do not synthesize precursors of peptidoglycan. The cell boundary is formed by a plasma membrane. Highly pleomorphic, ranging from coccoid to filamentous and even mycelioid cells. The method of reproduction is uncertain, but it includes binary fission, budding, and the release of "elementary bodies." Nonmotile. Gram negative. Colonies are minute, tend to grow down into solid media, and have a characteristic "fried-egg" appearance. These organisms may be saprophytic, parasitic, or pathogenic. Mycoplasmatales Freundt 1955, 71 remains the type order.

The proposals presented here may be summarized in a key showing the main differential characteristics of the taxa under consideration:

(I) Cells, generally small $(0.2$ to $10 \mu \mathrm{m})$, in which the nucleoplasm is not membrane bounded. Cell division is not accompanied by cyclical changes of nucleoplasm or cytoplasm.

Kingdom Procaryotae

(A) Cells that have a rigid or semirigid cell wall, containing peptidoglycan, and in which the Gram reaction is negative

Division I. Gracilicutes

(1) Phototrophs able to carry out a photolithotrophic or photoorganotrophic metabolism.
Class I. Photobacteria

(a) Carry out an aerobic phototrophic metabolism using water as an electron donor and producing water.

Subclass I. Oxyphotobacteriae

(i) Cells contain chlorophyll $a$ and phycobiliproteins

Order I. Cyanobacteriales

(ii) Cells contain chlorophyll $a$ and $b$; phycobiliproteins are not present.

Order II. Prochlorales

(b) Carry out a phototrophic metabolism under anaerobic conditions.

Subclass II. Anoxyphotobacteriae

(i) Cell membranes contain bacteriochlorophyll $a$ or $b$, the pigments being located on internal membrane systems continuous with the cytoplasmic membrane.

Order I. Rhodospirillales

(ii) Cell membranes contain bacteriochlorophyll $c, d$, or $e$ and small amounts of $a$ in "chlorobium vesicles."

Order II. Chlorobiales

(2) Do not have a phototrophic metabolism

Class II. Scotobacteria

(B) Cells that have a rigid or semirigid cell wall containing peptidoglycan and in which the Gram reaction is positive.

Division II. Firmacutes

(C) Cells that do not have a rigid or semirigid cell wall.

Division III. Mollicutes

\section{ACKNOWLEDGMENTS}

We are indebted to the Trustees and Trustees Emeriti of the Bergey Manual Trust for their frank and helpful comments; to Norbert Pfennig for valuable suggestions in naming the phototrophic bacteria; to R. Y. Stanier, who first pointed out and insisted upon the fundamental differences between gram-positive and gram-negative bacteria and who made many pertinent suggestions; and to the late $\mathrm{S}$. T. Cowan, whose concise and typically heretical comment "I don't like high ranks of bacteria" was a special stimulus. This paper is dedicated to him.

\section{REPRINT REQUESTS}

Address reprint requests to: Dr. R. G. E. Murray, Department of Bacteriology and Immunology, University of Western Ontario, London, Ont., Canada N6A 5C1.

\section{LTERATURE CITED}

1. Allsopp, A. 1969. Phylogenetic relationships of the Procaryota and the origin of the eucaryotic cell. New Phytol. 58:591-612.

2. Bavendamm, W. 1924. Die farblosen und roten Schwefelbakterien des Suss- und Salzwassers, p. 1-156. In Kolkwitz (ed.), Pflanzenforsch. Fischer, Jena.

3. Breed, R. S., E. G. D. Murray, and N. R. Smith (ed.). 1957. Bergey's manual of determinative bacteriology, 7th ed. The Williams and Wilkins Co., Baltimore. 
4. Buchanan, R. E., and N. E. Gibbons (ed.). 1974. Bergey's manual of determinative bacteriology, 8 th ed. The Williams and Wilkins Co., Baltimore.

5. Chatton, E. 1937. Titres et travaux scientifiques. Seta, Sottano.

6. Cohn, F, 1872. Organismen in der Pockenlymphe. Virchows Arch. Pathol. Anat. Physiol. 55:229-238.

7. Copeland, H. F. 1938. The kingdoms of organisms. Q. Rev. Biol. 13:383-420.

8. Copeland, H. F. 1956. The classification of the lower organisms. Pacific Books, Palo Alto, Calif.

9. Edward, D. G. ff., and E. A. Freundt. 1967. Proposal for Mollicutes as name of the Class established for the Order Mycoplasmatales. Int. J. Syst. Bacteriol. 17:267-268.

10. Enderlein, G. 1925. Bakterien-Cyclogenie Prolegomena zu Untersuchungen uber Bau, geschlechtliche und ungeschlechtliche Entwicklung der Bakterien. Walter de Gruyter \& Co., Berlin.

11. Haeckel, D. 1866. Generelle Morphologie der Organismen. Reimer, Berlin.

12. Haeckel, E. 1894. Systematische Phylogenie. Pt. 1. Systematische Phylogenie der Protisten und Pflanzen. Reimer, Berlin.

13. Kirchner, O. 1878. Algen, p. 1-284. In F. Cohn (ed.), Kryptogamenflora von Schleisen, vol. 2.

14. Lapare, S. P., P. H. A. Sneath, D. F. Lessel, V. B. D. Skerman, H. P. R. Seeliger, and W. A. Clark (ed.). 1975. International code of nomenclature of bacteria. (bacteriological code, 1976 revision). American Society for Microbiology, Washington, D.C.

15. Lewin, R. A. 1976. Naming the blue greens. Nature (London) 259:360.

16. Lewin, R. A. 1976. Prochlorophyta as a proposed new division of algae. Nature (London) 261:697-698.

17. Lewin, R. A. 1977. Prochloron, type genus of the Prochlorophyta. Phycologia 16:217.

18. Margulis, L. 1974. The classification and evolution of procaryotes and eucaryotes, p. 1-41. In R. C. King (ed.), Handbook of genetics, vol. 1. Bacteria, bacteriophages and viruses. Plenum Press, New York.

19. Murray, R. G. E. 1962 . Fine structure and taxonomy of bacteria, p. 119-144. In G. C. Ainsworth and P. H. A.
Sneath (ed.), Microbial classification, 12th Symposium, Society for General Microbiology. Cambridge University Press, Cambridge.

20. Murray, R. G. E. 1968. Microbial structure as an aid to microbial classification and taxonomy. Spisy Fac. Sci. Univ. Purkyne (Brno) 43:245-252.

21. Murray, R. G. E. 1974. A place for bacteria in the living world, p. 4-10. In R. E. Buchanan and N. E. Gibbons (ed.), Bergey's manual of determinative bacteriology, 8th ed. The Williams and Wilkins Co., Baltimore.

22. Pfennig, N., and H. G. Trüper. 1971. Higher taxa of phototrophic bacteria. Int. J. Syst. Bacteriol. 21:17-18.

23. Rabenhorst, L. 1863. Kryptogamen-Flora von Sachsen der Ober-Lausitz Thüringen und Nordbohmen mit Berücksichtung der benachbarten Länder. Erste Abt. E. Kummer, Leipzig.

24. Sachs, J. 1874. Lehrbuch der Botanik, 4 Aufl. W. Engelmann, Leipzig.

25. Schleifer, K. H., and O. Kandler. 1972. Peptidoglycan types of bacterial cell walls and their taxonomic implications. Bacteriol. Rev. 36:404-477.

26. Sonea, S., and M. Panisset. 1976. Pour une nouvelle bactériologie. Rev. Can. Biol. 35:103-167.

27. Stanier, R. Y. 1961. La place des bactéries dans le monde vivant. Ann. Inst. Pasteur (Paris) 101:297-312.

28. Stanier, R. Y., and C. B. van Niel. 1941. The main outlines of bacterial classification. J. Bacteriol. 42:437-466.

29. Stanier, R. Y., and C. B. van Niel. 1962. The concept of a bacterium. Arch. Mikrobiol. 42:17-35.

30. Trüper, H. G. 1976. Higher taxa of the phototrophic bacteria: Chloroflexaceae fam. nov., a family for the gliding, filamentous, phototrophic "green" bacteria. Int. J. Syst. Bacteriol. 26:74-75.

31. von Naegeli, C. 1857. In R. Caspary (ed.), Bericht über die Verhandlungen der Bot. Sekt. der 33 Versammslung deutscher Naturforscher und Ärtze, gehalten in Bonn von 18 bis 24 Sept. 1857. Bot. Z. 15:747-776.

32. Wallroth, F. G. 1833. Flora Cryptogamica Germaniae. In M. J. Bluff and C. A. Fingerhuth (ed.), Compendium Florae Germanicae 2:1-923.

33. Whittaker, R. H. 1969. New concepts of kingdoms of organisms. Science 163:150-160. 